\title{
Gastric Neuroendocrine Tumor pT3 TNM Finding v8
}

National Cancer Institute

\section{Source}

National Cancer Institute. Gastric Neuroendocrine Tumor PT3 TNM Finding v8. NCI

Thesaurus. Code C135039.

Gastric neuroendocrine tumor invading through the muscularis propria into subserosal tissue without penetration of overlying serosa. (from AJCC 8th Ed.) 